\title{
Residential Associations as State Actors: Regulating the Impact of Gated Communities on Nonmembers
}

\author{
David J. Kennedy
}

[T] he gated and walled community is a new phenomenon on the social scene, and, in the spirit of the foregoing pronouncement, the ingenuity of the law will not be deterred in redressing grievances which arise, as here, from a needless and exaggerated insistence upon private property rights ... [that] results in a pointless discrimination which causes serious financial detriment to another. ${ }^{1}$

Thirteen years later, the optimism of a California Court of Appeal seems unwarranted. As the number of residential associations has increased, the consequent litigation has arisen largely in the context of disputes between residential associations and their members over the content of frequently intrusive rules and regulations. Legal scholarship has followed this trend. Reading the endless paeans to liberty of contract, one might fail to recognize the serious externalities that accompany residential associations, affecting nonmembers who were party to no contract. Residential associations and gated communities often restrict nonmembers' freedom of speech, limit nonmembers' freedom of movement, and engage in racial discrimination against nonmembers. In identifying some of the social problems created and exacerbated by residential associations, this Note will suggest an appropriate legal framework within which these burdens may be analyzed.

Variously known as homeowners' associations, gated communities, and property owners' associations, ${ }^{2}$ residential associations are an increasingly

1. Laguna Publishing Co. v. Golden Rain Found., 182 Cal. Rptr. 813, 826 (Ct. App.), appeal dismissed for want of a substantial federal question, 459 U.S. 1192 (1982).

2. "Residential community associations," or "RCAs," is the term used in UNITED STATES ADVISORY COMM'N ON INTERGOVERNMENTAL RELATIONS, RESIDENTIAL COMMUNITY ASSOCIATIONS: PRIVATE GOVERNMENTS IN THE INTERGOVERNMENTAL SYSTEM? (1989) [hereinafter ACIR REPORT]. Additionally, the term "residential association" seems preferable to the equally common "homeowners' association" since the association does not truly belong to the homeowners: "[T]he developer possesses nearly absolute control over the community." Uriel Reichman, Residential Private Governments: An Introductory Survey, 43 U. CHI. L. REV. 253, 286 (1976). The developer also lays much of the legal foundation for the association. See Robert Jay Dilger, Neighborhood POLITICS: Residential COMMUNITY AsSOCIATIONS IN AMERICAN GOVERNANCE 12-14 (1992). 
popular option for Americans weary of crime, social ills, and the inability of government to address these pressing concerns. In form, residential association agreements are ownership deeds that require membership in the association, ${ }^{3}$ assess mandatory dues to fund the services provided by the association, and specify a number of covenants, conditions, and restrictions (CC\&Rs) governing the behavior of members. ${ }^{4}$ Residential associations have many different structures, including condominium projects, but eighty percent involve the administration of territory such that they resemble communities in the broader sense rather than simply buildings. ${ }^{5}$

While a great deal has been written about residential associations, ${ }^{6}$ the literature has largely concentrated on disputes between residential associations and their members. Particularly fertile ground for attention have been the many colorful lawsuits contesting the rules and regulations of residential associations, banning as a threat to community order such things as basketball hoops over garages, ${ }^{7}$ heavy dogs, ${ }^{8}$ cats of any weight, ${ }^{9}$ too many poodles, ${ }^{10}$ or

Although the major text in this area uses the term "Property Owners Association," see RoBERT G. NATELSON, LAW OF PROPERTY OWNERS ASSOCIATIONS (1989), this fails to convey adequately the communal nature of certain parts of the property. Other commonly used appellations are "planned unit developments" (PUDs), a term not employed in its literal sense, but intended simply to refer to certain residential arrangements, id., and "common interest developments" (CDDs), see EVAN MCKENZIE, PRIVATOPIA: HOMEOWNER ASSOCIATIONS AND THE RISE OF RESIDENTIAL PRIVATE GOVERNMENTS (1994).

3. One guide to residential associations defines a "Property Owners Association" as "an organization regulating and/or providing services for a land subdivision, which organization is created by covenants running with the land and whose membership consists of holders of units in the subdivision." NATELSON, supra note 2 , at 3 .

4. ACIR REPORT, supra note 2, at 3. Some CC\&Rs are quite specific and eminently sensible: Bylaw VI $\$ 7(k)$ of the Bailey, a condominium in Washington, D.C., provides that "No Barry Manilow records, tapes or CDs may be owned or played on the premises." Carl B. Kress, Beyond Nahrstedt: Reviewing Restrictions Governing Life in a Property Owner Association, 42 UCLA L. REv. 837, 840 n.12 (1995).

5. See ACIR REPORT, supra note 2 , at 12 . Note that "territory," defined broadly, may include certain condominium associations.

6. The definitive text on the topic is NATELSON, supra note 2. See also Robert C. Ellickson, Cities and Homeowners Associations, 130 U. PA. L. REV. 1519 (1982); Gerald E. Frug, Cities and Homeowners Associations: A Reply, 130 U. PA. L. REV. 1589 (1982); Wayne S. Hyatt \& James B. Rhoads, Concepts of Liability in the Development and Administration of Condominium and Home Owners Associations, 12 WAKE FOREST L. REV. 915 (1976); Reichman, supra note 2; Note, The Rule of Law in Residential Associations, 99 HARV. L. REV. 472 (1985).

7. A Newport Beach, California, residential association attempted to prevent one homeowner from keeping her family's basketball hoop over the garage door. After fighting the suit for eight years, at a cost of over $\$ 10,000$ to the homeowner, the parties settled, allowing the hoop to remain. See DiLGER, supra note 2 , at 61 .

8. In a celebrated dispute from Boca Raton, one homeowners' association resident was required to attend a court-supervised weigh-in of his $291 / 2$-pound dog. The association's CC\&Rs specified a 30-pound limit for pets; his was suspected of being overweight. See Karen E. Klein, Code Blues: Rules That Govern Life in Homeowners' Associations Are Being Challenged in Court by Angry Owners, L.A. TMES, Mar. 5, 1995, at K1.

9. The California Supreme Court recently upheld a condominium association's prohibition on animals against a resident who sued rather than have her three cats deported. See Nahrstedt v. Lakeside Village Condominium Ass'n, 878 P.2d 1275 (Cal. 1994). The battle over the three felines, named "Boo-Boo," "Dockers," and "Tulip," was joined when Nahrstedt responded to the association's first removal order with, “"“'Don't you F- with my cats."”' Kress, supra note 4, at 851 n.70 (quoting Barbara Steuart, Cat Fight Over Condo Rights; How Far Can Condo Restrictions Go?, RECORDER, June 8, 1994, at 1); see also Sheri 
smooching grandparents. ${ }^{11}$ Yet there is another set of issues that has not received extended consideration. As the number of residential associations increases, conflicts with nonmembers over the use of public space and public resources will arise more frequently. The jurisprudential framework developed to referee disputes between associations and their members cannot apply with equal efficacy to disputes between associations and nonmembers. Courts must move from the domain of the law of contracts and servitudes to grapple with the impact of residential communities on outsiders, whether these outsiders challenge the community by attempting to prevent their establishment, ${ }^{12}$ objecting to their authority, ${ }^{13}$ or questioning their consumption of public resources. ${ }^{14}$

This Note will argue that the harms imposed on society by residential associations are significant and that courts should consider curtailing their power over nonmembers. Part I will discuss the reasons for the rise of the residential association as a form of semiprivate government. Part II will assess the often significant harms inflicted by residential associations on nonmembers. Finally, Part III will argue that the most appropriate way to limit these undesired effects on outside communities is through the application of the "state action" doctrine. The state action framework is particularly useful not because it would increase the degree of liability assumed by residential associations, although this would be the likely result, but because it best speaks to the nature of the problems involved. Residential associations cause harms to nonmembers by developing exclusive communities, by gating formerly public streets and neighborhoods, and by increasing the fiscal burdens of cities and states. Since the ability to wield such power is largely associated with the state, only by recognizing the quasi-governmental nature of these associations and their actions can the unique conflicts they engender be adequately addressed. ${ }^{15}$ Furthermore, treating residential associations as state actors will require them to assume a level of responsibility consistent with the powers they enjoy.

L. Marvin, California Supreme Court Survey February 1994-December 1994, 22 PEPP. L. REV. 1675, 1692-97 (1995).

10. See Dulaney Towers Maintenance Corp. v. O’Brey, 418 A.2d 1233 (Md. Ct. Spec. App. 1980) (upholding restriction limiting unit owners to one dog per unit).

11. "In Santa Ana, a 51-year-old grandmother received a warning citation from her condominium association for kissing a friend good night in her driveway." Richard Louv, Homeowner Group a Dubious New Ruler, SAN DIEGo UNION-TRIB., July 27, 1994, at A2.

12. See infra Subsection II.A.1.

13. See infra Subsections II.A.2-3.

14. See infra Section II.B.

15. Hence this analysis replies to the challenge issued by one devotee of residential associations: Unless a clear and convincing case is made that the residential private government infringes the constitutional rights of nonowners and that such a violation is so injurious as to outweigh the constitutionally protected rights of free association and property privileges of the homeowners, the public law route should not be considered.

Reichman, supra note 2, at 301 (footnote omitted). 
The question of whether to treat residential associations as state actors has been addressed by numerous state court decisions, producing little consensus. ${ }^{16}$ The difficulty of reconciling community with exclusion explains much of this ambivalence and confusion over how to treat these entities. ${ }^{17}$ On one hand, residential associations may be seen to embody cohesive, nurturing communities, a throwback to small-town American life, when people still had a sense of civic responsibility. On the other hand, small-town America has known its share of racial discrimination and exclusion of undesirables. It is difficult to say whether modern residential associations truly embody one paradigm or the other. Yet the growing number of Americans who live in residential associations, and the growing number affected by these associations, compel a thorough examination of their nature, the harms they cause, and possible remedies for these harms. This Note will suggest that treating residential associations as state actors is the proper approach to regulating these harms.

\section{THE RISE OF RESIDENTIAL ASSOCIATIONS}

\section{A. History and Numbers}

Voluntary associations seem to be constitutive of the American character. In 1835, Alexis de Tocqueville noted, "Americans of all ages, all conditions, and all dispositions, constantly form associations .... religious, moral, serious, futile, general or restricted, enormous or diminutive."18 Residential associations in particular, however, represent a relatively recent phenomenon. While they may be traced at least as far back as 1831, when Gramercy Park was formed in New York City, ${ }^{19}$ in 1962 there were still fewer than 500 homeowners' associations in the United States. ${ }^{20}$ The growth in the number

16. See, e.g., Riley v. Stoves, 526 P.2d 747 (Ariz. Ct. App. 1974) (holding that judicially enforced association age restriction constituted state action but rule was rationally related to legitimate objective); Laguna Publishing Co. v. Golden Rain Found., 182 Cal. Rptr. 813 (Ct. App.), appeal dismissed for want of a substantial federal question, 459 U.S. 1192 (1982) (holding that exclusion of newspaper from residential community by governing association contributed to finding of impermissible state action and violated publisher's rights secured by California Constitution); Brock v. Watergate Mobile Home Park Ass'n, 502 So. 2d 1380 (Fla. Dist. Ct. App. 1987) (holding that homeowners' association governing mobile home park was not state actor).

17. This is the main argument in Clayton P. Gillette, Courts, Covenants, and Communities, $61 \mathrm{U}$. CHI. L. REV. 1375 (1994). Gillette briefly considers the impact of residential associations on nonresidents, id. at $1431-41$, but believes that the call for scrutiny by courts would "swallow[] up the argument for judicial restraint," Id. at 1431 .

18. 2 AleXIS DE TOCQueville, Democracy IN AMERICA 114 (Phillips Bradley ed. \& Henry Reeve trans., 1945) (1835).

19. NATELSON, supra note 2, at 17. Another commentator views Gramercy Square merely as a "precedent" and maintains that Louisburg Square in Boston was actually the first residential association in the United States. See DILGER, supra note 2, at 43-44 (describing purpose of Louisburg Square Association); see also infra note 33.

20. MCKENZIE, supra note 2 , at 10. 
of residential associations since then is best described as "explosive." 21 In 1970 , there were 10,000 ; in $1980,55,000$; in $1990,130,000$; and in 1992 , 150,000 , covering thirty-two million people, ${ }^{22}$ or roughly twelve percent of the population. ${ }^{23}$ Some insist that the number of residential associations even exceeds the number of cities. ${ }^{24}$

Residential associations come in three basic forms: condominium associations; homeowners' associations, which involve the management of common property; and cooperative associations. Roughly fifty-five percent of residential associations are condominium associations; the remaining forty-five percent are almost all homeowners' associations. ${ }^{25}$ This Note will concentrate on homeowners' associations because they generate far greater friction with nonmembers than do condominiums. ${ }^{26}$ For the purposes of this Note, therefore, the phrase "residential association" refers largely to a neighborhood whose members have decided to wall themselves off or privatize their streets rather than to a condominium development that has dominion over little besides a cul-de-sac and a parking lot.

\section{B. Explanations for Expansion}

Primary among the motivations to join a residential association is the perceived increase in security the development provides. Most important for the residents of Rotonda condominiums in northern Virginia, for example, is that "they feel safe."27 The concern for safety has led most associations to employ private security guards; some have taken the additional precaution of constructing gates or even moats. ${ }^{28}$ In fact, partially as a result of the growth

21. NATELSON, supra note 2 , at 32.

22. MCKENZIE, supra note 2, at 10-11; see also DILGER, supra note 2, at 49 (maintaining that 1960s marked "basic watershed" in residential association growth). A more recent report distinguishes between the 28 million who live in an area govemed by a private community association and the 4 million who live in a closed-off or gated community. Timothy Egan, Many Seek Security in Private Communities, N.Y. TIMES, Sept. 3, 1995, at A1, A22.

23. See ACIR REPORT, supra note 2, at 4 (basing percentage on figure of 29 million). These astronomical figures, moreover, are underestimates, as membership in and reporting to the national Community Associations Institute (CAI), which supplies these statistics, are voluntary. Id.

24. See Ellickson, supra note 6, at 1520 . Residential associations are most common in California, Florida, Texas, New Jersey, Maryland, and Virginia. ACIR REPORT, supra note 2, at 11. The report notes that "[t]his reflects the distribution of CAI membership, but probably understates the number of RCAs, particularly in New York." Id. They are least common in the Midwestern states. See id. (reporting that only $10 \%$ of CAI-member RCAs are located in Midwest).

25. ACIR REPORT, supra note 2, at 11. Cooperative associations constitute less than two percent of all associations. Id.

26. Note that the public rights to access and freedom of movement are attenuated if we are concerned with a condominium development; the public at large has a much weaker right, if any, to walk in the common hallways of a condominium project than to travel on public streets. Thus while much of this Note will not apply to self-contained condominium units, such units may still impose burdens on the outside world by, for example, requesting tax deductions for their association dues. See infra Subsection II.B.2.

27. Ann Mariano, Enclosed Communities: Havens, or Worse? As Numbers Grow, Critics See Ominous Trend of Segregating Residents by Income, Age, Race, WASH. POST, Apr. 9, 1994, at E1.

28. Id. at E6. 
in popularity of residential associations, "the total number of private security guards in the United States now exceeds the number of public police officers." ${ }^{29}$ Some communities take even more extensive precautions: "Walls are only the beginning. Inside may be surveillance cameras, infrared sensors, motion detectors .... St. Andrews, a gated community in Boca Raton, Florida, spends over $\$ 1$ million a year on helicopters and canine patrols. ${ }^{.30}$

Compounding this protective attitude toward personal security is the growing sense that government has failed to do enough to preserve property values. The national Community Associations Institute (CAI) cites the "greatly diminished confidence in the capability of the nation's basic institutions to meet public needs" as an important reason for the popularity of associations. ${ }^{31}$ Joining a residential association has the benefit of preserving and enhancing the value of what is often one's largest investment: one's home and the real estate on which it is situated. Concern for property values, therefore, explains much of the popularity of residential associations, and the associations' CC\&Rs reflect this priority. Seemingly onerous and arbitrary restrictions have been upheld in a variety of courts on the ground that they maintain the character of the community and thus the value of the real estate within it. ${ }^{32}$

Furthermore, the racial and economic homogeneity fostered by many residential associations is not without appeal for some homebuyers. While it would certainly be an exaggeration to attribute racist or classist sentiments to all members of these associations, such organizations provide a potent means of retreating into homogeneous enclaves undisturbed by the undesirably different. ${ }^{33}$ Whether this community structure is largely an attempt to exclude

29. Robert B. Reich, Secession of the Successful, N.Y. TIMES, Jan. 20, 1991, § 6, at 16, 42.

30. David Dillon, Fortress America, Planning, June 1994, at 8, 8.

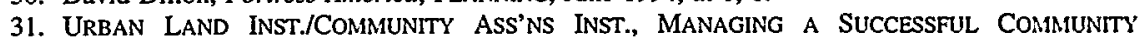
AsSOCIATION 2 (1974), quoted in MCKENZIE, supra note 2, at 137. The Institute continues, "the CA [Community Association] has emerged as a new, close-to-home institution through which citizens can have a very real role in influencing those affairs that shape their lives and those of their families, as well as their environment." Id.

32. See, e.g., Amoco Realty Co. v. Montalbano, 478 N.E.2d 860, 862 (Ill. App. Ct. 1985) (affirming grant of injunction to developer of residential community enforcing restriction on use of residential property for business purposes), which cites the declaration of trust's commitment to "the distinctive qualities, amenities and characteristics of the area so that it would at all times be regarded as a residential community of outstanding excellence." Id. In Lyons v. King, 397 So. 2d 964, 965, 968 (Fla. Dist. Ct. App. 1981) (affirming trial court judgment that association did not act in "arbitrary and unreasonable manner" in refusing to approve prospective purchasers who intended to rent rather than occupy unit), the court relied on the association's stated interest in maintaining "a community of congenial residents who are financially responsible and thus protect the value of the apartments." Id. But see Robert G. Natelson, Consent, Coercion, and "Reasonableness" in Private Law: The Special Case of the Property Owners Association, 51 OHIO ST. L.J. 41, 44 (1990) (arguing that courts have "severely limited an association's power to engage in community enhancement").

33. One of the first residential associations in the country served this very purpose: Louisburg Square on Boston's Beacon Hill employed use and occupancy restrictions to keep out "Negroes, Irish, [and] Mongolians," among others. John McClaughry, Private Idahoes, REASON, Aug./Sept. 1995, at 54, 54-55 (reviewing Dilger, supra note 2, FRED FOldVARY, PUBLIC GOODS AND PRIVATE COMMUNITIES (1994), and MCKENZIE, supra note 2). 
racial minorities or the poor is a difficult question. ${ }^{34}$ Robert Reich, now Secretary of Labor, insisted in 1991 that, "racial exclusion is neither the primary motive for the separation nor a necessary consequence. Lower-income whites are similarly excluded, and high-income black symbolic analysts are often welcomed."35 Reich's observation, however, can also be explained by the fact that discrimination on the basis of class is largely immune from legal challenge while discrimination on the basis of race is not. ${ }^{36}$ Whatever the sort of division sought, however, residential associations may serve as a powerful tool for segregation.

In sum, residential associations have a powerful appeal for the "Morning in America" crowd. One gated community advertises by asking prospective buyers to imagine "a "perfect place to live ... outside the pandemonium of the city', where there can be 'a return to simpler times, when you knew you were secure within the boundaries of your own neighborhood... [and] where children could play unattended and be safe after dark." ${ }^{37}$ The growth of residential associations testifies to the widespread feeling that crime has spun out of control and that the state has allowed the social fabric to unravel and is impotent to stop this decay. Yet left unchecked, the separatism of residential associations will likely hasten this disintegration. The next part of this Note describes how allowing the untrammeled enjoyment of benefits by the seceding few creates a wide variety of problems affecting both the rights and the welfare of nonmembers.

\section{HARMS IMPOSED by RESIDENTIAL AsSOCIATIONS}

The development of a residential association does not simply bring an improvement in the lives of its members; it affects members of the wider community who are compelled to forgo their rights to what was once public space. Far from losing merely the "freedom to walk, stroll, or loaf,",38 nonmembers must forfeit their right to live in certain areas, their right to move about freely, their constitutional guarantees of equal protection and due process, and their right to a fair share of the public fisc. These deprivations,

34. Note, however, that even poor minority communities may have residential associations. In Los Angeles, several public housing projects have gated themselves off to defeat crime. As one resident of Mar Gardens explains, "'Ve want the same protection as white folks." Dillon, supra note 30, at 8; see also David Beard, Puerto Rico Building Walls to Keep Out Crime; Some Say "Closed Communities" Will Aggravate Effects of Economic Segregation, L.A. TimES, Aug. 2, 1992, at A4 (noting that both suburbs and housing projects in Puerto Rico have begun walling themselves off).

35. Reich, supra note 29 , at 45 .

36. See infra note 39.

37. Dilion, supra note 30 , at 9 (alterations in original). Or, put less lyrically, residential associations facilitate "[t]he protection of property values, the preservation of social status and the defense of the psychological and emotional benefits derived from a familiar and dependable environment." Richard Briffault, Our Lacalism: Part II-Localism and Legal Theory, 90 CoLuM. L. REv. 346, 372 (1990).

38. Doe v. Bolton, 410 U.S. 179, 213 (1973) (Douglas, J., concurring). 
most importantly, are linked directly to the residential association's unacknowledged but de facto status as a quasi-governmental organization. Residential associations enjoy a degree of power virtually equal to that of municipal governments but assume none of the corresponding liabilities.

\section{A. Who Is Excluded?}

\section{The Case of the South Carolina Sea Islands}

The very establishment of a residential association is fraught with potential for discrimination on the basis of race and class. ${ }^{39}$ Despite decades of commitment to racial integration, the United States continues to fall short in providing equal opportunity to black homeowners, perpetuating a culture of division and domination. ${ }^{40}$ Whether intentionally or unintentionally, developers often feed these discriminatory forces and thereby taint subsequent grants of authority by states or municipalities to residential associations. A case in point is Hilton Head, South Carolina. Farned for hosting the Renaissance Weekend retreat for baby boom wunderkinder, ${ }^{41}$ Hilton Head may be equally well known for its system of exclusive property developments, named, with apparent lack of concern for historical irony, "plantations." These gated resort villages, with names such as Shipyard Plantation, Port Royal Plantation, Wexford Plantation, Colleton River Plantation, and Hilton Head Plantation, are occupied largely by the wealthy and white, to the exclusion of the local black population. ${ }^{42}$ As one local historian acidly commented, "It used to be you couldn't get off the plantations. Now you can't get on." ${ }^{\prime 43}$

39. Of course, discrimination on the basis of class is not unconstitutional. San Antonio Indep. Sch. Dist. v. Rodriguez, 411 U.S. 1 (1973) (holding that Texas school financing scheme resulting in educational disparities between poor and wealthy districts did not violate Fourteenth Amendment). Indeed, the state frequently makes a variety of policy decisions that, although facially neutral, may have undesirable classbased discriminatory effects.

40. See Douglas S. Massey \& NanCy A. Denton, American APartheid: SEgregation and the MAKING OF THE UNDERCLASS 221-23 (1993) (demonstrating that with respect to housing, "racial segregation still constitutes a fundamental cleavage in American society"); see also Richard Thompson Ford, The Boundaries of Race: Political Geography in Legal Analysis, 107 HARV. L. REV. 1843, 1847 (1994) (citing MASSEY \& DENTON, supra).

41. Renaissance attendees have included President Clinton. See Todd S. Purdum, The President Welcomes '95 with Old Songs and Friends, N.Y. TIMES, Jan. 2, 1995, \$ 1, at 9.

42. Peter Applebome, Tourism Enriches an Island Resort, But Hilton Head Blacks Feel Left Out, N.Y. TIMES, Sept. 2, 1994, at A18. Hilton Head is by no means unique in this respect. For example, "[a]t Society Hill [a residential association in New Jersey], a group of residents appeared surprised when a stranger remarked on the absence of Blacks among them. 'I never noticed it until you asked,' said David DeLuca, treasurer of the homeowners' association." Diana Jean Schemo, Escape from Suburbia: Community Associations Thrive Amid Debate on Freedom, Privacy and Democracy, N.Y. TIMES, May 3, 1994, at B1, B6.

43. Applebome, supra note 42, at A18 (quoting Daufuskie historian Billie Burn). It is true that Hilton Head plantation members include black basketball star Michael Jordan, $i d$., but these exceptions are few, far between, and exceedingly wealthy. 
The burgeoning development of resorts like Hilton Head has mobilized efforts to build other plantations on islands off the South Carolina coast. As "the ... coast is increasingly becoming a walled resource," Island, for example, has become more and more a focus of developers' attention. Daufuskie is inhabited mostly by the Gullah people, descendants of freed slaves who have largely preserved their language and West African culture. ${ }^{45}$ The NAACP Legal Defense Fund has alleged that the owner of one plantation, International Paper Corporation, colluded with the Beaufort County government to coerce the Gullah people to leave Daufuskie through tax increases, land seizures, and inadequate public services. ${ }^{46}$ In addition to throwing into stark relief the racial implications of market forces in shaping developers' choices, ${ }^{47}$ the Daufuskie dispute also illustrates the possibility that local governments will collude with developers to create attractive residential associations even at the price of encouraging racial discrimination. ${ }^{48}$ As subsequent sections of this Note will argue, the reliance upon state power to effect discrimination has profound constitutional implications.

\section{The Problem with Private Streets}

A more common demonstration of the power of residential associations is the "private streets" movement. While some developers resort to the argument that they simply built upon barren property unencumbered by any public claim, demands that municipalities declare streets to be private reveal clear cases of removing property from the public realm and excluding nonmembers. Both total and partial exclusion raise issues of due process and equal protection: Disposition of a public resource is made by a small number of people who decide what restrictions will apply to "their" streets; these restrictions, in turn, may provide a wide range of discretion to security personnel, resulting in discriminatory enforcement of the association's regulations. Even if

44. Frank Hefiin, Closed Gates Trouble Outsiders, Progressive, Oct. 1993, at 32, 32. For an extensive discussion of Gullah culture and society, see PAT CONROY, THE WATER IS WIDE (1972) (describing author's experience as teacher in Gullah school).

45. Developers Accused of Anti-Black Move, Plain DEALER, Nov. 19, 1992, at 10A.

46. Developer Denies Civil Rights Allegations, WASH. POST, Nov. 21, 1992, at A11. Officials from the 25-million-member National Council of Churches declared in 1990 that developers on Hilton Head "were committing 'cultural genocide." Heflin, supra note 44, at 33. After a three-year struggle, the LDF and the developers eventually reached an agreement by which development would continue without forcing more residents off the island. See Harvey Berkman, The Battle of "Hilton Head II," NAT. L.J., Dec. 19, 1994, at A4.

47. There are environmental considerations as well. Frequently, residential associations "are named for the species or landscape that was eliminated to make way for the development." Egan, supra note 22, at A22 (citing JOEL GARREAU, EDGE CITY: LIFE ON THE NEW FRONTIER 471 (1991) "You name a place for what is no longer there as a result of your actions.")).

48. Residential associations may also demand other limitations on the use of their property, encouraging local governments to employ restrictive zoning and land-use policies. Briffault suggests that "the emergence of the independent residential suburb may have contributed to the judicial endorsement of local exclusionary practices." Briffault, supra note 37 , at 368. 
discrimination is not the issue, gated communities violate the right to travel ${ }^{49}$ by preventing nonmembers from using formerly public streets.

In many places, the privatization of formerly public property is well advanced. Ladue and Olivette, for example, two small suburban towns in St. Louis County, Missouri, are "virtually blanketed" by private-street organizations. ${ }^{50}$ The major service these associations provide, in addition to street lighting and security patrols, is the barricading or chaining off of their streets, effectively closing entire swathes of the township to other residents. ${ }^{51}$ Nearby St. Louis has also experimented extensively with a policy of allowing associations to close off once-public streets. The city essentially transfers the deed to association residents on the condition that they accept responsibility for the neighborhood. ${ }^{52}$ Advocates insist that the program has resulted in more cohesive, stable, and safe neighborhoods. ${ }^{53}$

Yet private streets may well inflict harms on the outside community. In a 1994 California case, Citizens Against Gated Enclaves v. Whitley Heights Civic $A s s^{\prime} n{ }^{54}$ a group of Los Angeles homeowners proposed to privatize their streets out of concern for increasing violence, crime, and graffiti. The streets that were to become private were part of a historic neighborhood, in which many of the homes had been designed by noted architects. ${ }^{55}$ In addition to being deprived of access to these homes, nonmembers would have been unable to use the formerly public streets and sidewalks for commuting to work or jogging. ${ }^{56}$ Some of these individuals formed Citizens Against Gated Enclaves

49. See Dunn v. Blumstein, 405 U.S. 330, 338-39 (1972) (striking down durational residency requirement for receipt of welfare benefits as violative of constitutionally protected right to travel). The Court in Dunn emphasized that, "The right to travel is an 'unconditional personal right,' a right whose exercise may not be conditioned." Id. at 341 (citing Shapiro v. Thompson, 394 U.S. 618, 643 (1969)). Note that although the law at issue in Shapiro affected interstate travel, the Court broadened this principle in Dunn to strike down a law affecting intercounty travel. See id. at 334.

50. Ladue has 143 subdivisions, with a total population of approximately 9000 , while Olivette has 90 subdivisions, with a total population of around 8000 . Ronald J. Oakerson, Private Street Associations in St. Louis County: Subdivisions as Service Providers, in ACIR REPORT, supra note 2, at 55, 56. The town of Ladue is the municipality made famous by the Supreme Court's decision in City of Ladue v. Gilleo, 114 S. Ct. 2038 (1994) (striking down city ordinance prohibiting placement of pro-peace sign on private citizen's property). Note that the restriction at issue in that case was enacted by the town, not one of the residential associations within the town. While the Court did not address the question of whether an association would have been able to enact a similar restriction, much of the case law in this area suggests that such a restriction would be possible. See infra text accompanying notes 98-102. According to a 1990 analysis, the town of Ladue was one of the ten richest incorporated communities in America. Briffault, supra note 37 , at 353 n. 43 .

51. See Oakerson, supra note 50 , at 55 .

52. See Robert H. Nelson, The Privatization of Local Government: From Zoning to RCAs, in ACIR REPORT, supra note 2, at $45,49$.

53. See id; see also Maggie Jessup, Suburbanites Putting their Backs to the Wall: Gates, Guards, Become Sought-After Amenity, ATLANTA J. \& CONST., Apr. 14, 1994, at J1.

54. 28 Cal. Rptr. 2d 451 (Ct. App. 1994).

55. Id. at 452 .

56. Id. at 453 . 
(CAGE) and won an injunction in both superior court and in a court of appeal to prevent the privatization of the streets. ${ }^{57}$

The legal issue of the accessibility of gated communities or private streets to nonmembers acquires an additional level of complexity when security guards or private police are present. Where exclusion is partial and made on a case-by-case basis, security personnel must make their own decisions as to which pedestrians are desirable and which are not. The result, as one planning consultant bluntly put it, is that "'[a] black person who shows up in one of these places is likely to get busted."'58 Worse, those unfairly harassed or unjustifiably asked to leave because of their race or class have little or no recourse as the residential association is purportedly a purely private entity. Some associations circumvent the problem of discretion by imposing an entry fee, which excludes the very poor: Sea Pines Plantation in Hilton Head, for example, allows pedestrian access for a three-dollar fee. ${ }^{59}$ Such partial exclusion by race or by class is in many ways worse than the total exclusion of all pedestrian traffic; while the latter affects more people, the former more explicitly reveals the social prejudices that lie behind the impulse to exclude.

The ability of residential associations to carry out any type of exclusion, moreover, demonstrates that more is at issue here than segregation by income. It might be argued that residential associations simply embody in design what high-priced suburbs achieve in practice. Yet while expensive housing markets may prevent certain individuals from living in certain areas, residential associations have the additional power to prevent such individuals from even entering these areas. This distinction is roughly equivalent to the difference between the steering of minority homebuyers away from certain neighborhoods and outright Jim Crow-type laws. While the legality of class-based discrimination prevents the elimination of all harms created by residential associations, the proposal of this Note attempts to correct as many negative externalities as possible given this limitation.

\section{Restrictions on Freedom of Speech}

Closing off entire sections of the community to outsiders or, more problematically, perceived troublemakers, also has the clear effect of stifling speech in those neighborhoods. Both political and commercial speech are muzzled when, for example, "[t]here are no pesky doorbellers, be they politicians or Girl Scouts, allowed inside [a] community." members of the association may have agreed to such limitations by signing the

\footnotetext{
57. Id. at 457 (citing "fundamental public interest" in use of streets).

58. Dillon, supra note 30, at 10-11 (quoting Daniel Lauber of River Forest, Illinois).

59. Heflin, supra note 44 , at 33 .

60. Egan, supra note 22 , at A1.
} 
CC\&Rs when they moved in, nonmembers certainly did not consent to the same sacrifices.

The restrictions on speech that can result from residential associations are well illustrated by the 1982 California case of Laguna Publishing Co. v. Golden Rain Foundation, ${ }^{61}$ the only prominent case thus far in which nonmembers have prevailed against a residential association's restrictions on freedom of speech. A California Court of Appeal held that the Leisure World development near Los Angeles could not prevent promotional distribution of a newspaper to its members simply because it was not Leisure World's own in-house paper. The court emphasized that the prohibition against distribution of newspapers turned the association's membership into a captive audience for the in-house paper. Having allowed distribution of one publication, Leisure World could not then engage in viewpoint discrimination by disallowing the distribution of others. ${ }^{62}$ Leisure World's restriction on speech by nonmembers dramatically illustrates the ability of developers to create a captive audience, access to which may then be auctioned off to the highest bidder. Where such communities are the dominant form of residential living, less well-financed or less popular viewpoints run the risk of being heard rarely if at all.

In addition to expressing profound concern about the harms caused by the exclusionary powers of residential associations, ${ }^{63}$ the Laguna court made clear its debt to the 1945 Supreme Court decision in Marsh v. Alabama, ${ }^{64}$ which upheld the right of a Jehovah's Witness to distribute religious leaflets in Chickasaw, Alabama, a company town in which every street was owned by a private corporation. Although the modern analogs to Marsh could well be cases concerning residential associations, thus far its logic has been applied far more frequently in cases involving shopping malls that seek to limit free speech on their premises. The conflict between mall owners and speakers or petitioners has had varied results, largely owing to a 1976 Supreme Court decision holding that there is no federal constitutional right to free speech in shopping malls, ${ }^{65}$ which pushed the issue to the states for resolution. ${ }^{66}$

61. 182 Cal. Rptr. 813, 815 (Ct. App.), appeal dismissed for want of a substantial federal question, 459 U.S. 1192 (1982).

62. Id. at 829. This principle, however, does not extend to cable providers. See Cox Cable San Diego, Inc. v. Bookspan, 240 Cal. Rptr. 407, 409 (Ct. App. 1987) (holding that cable television provider had no First Amendment right of access to condominium development as cable television medium "differs significantly" from print medium).

63. See supra text accompanying note 1 .

64. Laguna, 182 Cal. Rptr. at 824 (citing Marsh v. Alabama, 326 U.S. 501 (1946)).

65. See Hudgens v. NLRB, 424 U.S. 507 (1976).

66. Mall owners have prevailed in Arizona, Connecticut, Georgia, Michigan, New York, North Carolina, Pennsylvania, Washington, and Wisconsin, largely on the ground that they are not state actors. See Fiesta Mall Venture v. Mecham Recall Comm., 767 P.2d 719 (Ariz. Ct. App. 1988); Cologne v. Westfarms Assocs., 469 A.2d 1201 (Conn. 1984); Citizens for Ethical Gov't, Inc. v. Gwinnett Place Assocs., 392 S.E.2d 8 (Ga. 1990); Woodland v. Michigan Citizens Lobby, 378 N.W.2d 337 (Mich. 1985); SHAD Alliance v. Smith Haven Mall, 488 N.E.2d 1211 (N.Y. 1985); State v. Felmet, 273 S.E.2d 708 (N.C. 1981); Western Pa. Socialist Workers 1982 Campaign v. Connecticut Gen. Life Ins. Co., 515 A.2d 1331 
Regardless of the outcomes of the mall cases, however, the Marsh principle that the right to freedom of speech should outweigh the property rights of owners should be much stronger in the case of residential associations. Although the vast expanse between J.C. Penney's and Sears may well lay a stronger claim to being the contemporary American agora than do public streets, the latter still maintain an important status in free speech jurisprudence. As the classic statement of the importance of free speech in public streets explains:

Wherever the title of streets and parks may rest, they have immemorially been held in trust for the use of the public and, time out of mind, have been used for purposes of assembly, communicating thought between citizens, and discussing public questions. Such use of the streets and public places has, from ancient times, been a part of the privileges, immunities, rights, and liberties of citizens. ${ }^{67}$

When communities are gated, however, the fora for speech are reduced, penalizing those who are not wealthy enough to purchase access.

Previous suggestions for protecting free speech rights against private developers are inadequate. One proposal for dealing with the conflict between free speech and private ownership of quasi-public fora is that "development permission be conditioned upon the owner's willingness to provide for expressive entry." 68 While preempting the exercise of potentially coercive power by residential associations is certainly a good idea, this approach wrongly assumes that municipalities will be willing to insist upon the protection of free speech rights even at the expense of losing a profitable development. Many local governments may well be willing to abet potentially unconstitutional behavior by gating a street or declaring it private. As the Daufuskie example demonstrates, local governments may even encourage discrimination by coercing residents to leave or make way for residential associations. Hence the best way to approach and control the harms resulting from this change in authority is to match the nature of the power exerted with a correspondingly higher level of responsibility.

(Pa. 1986); Southcenter Joint Venture v. National Democratic Policy Comm., 780 P.2d 1282 (Wash. 1989); Jacobs v. Major, 407 N.W.2d 832 (Wis. 1987).

Free speech advocates, however, have won in California, Massachusetts, New Jersey, and Oregon, largely on the ground that a mall is a public forum. See Robins v. Pruneyard Shopping Ctr., 592 P.2d 341, 347 (Cal. 1979), aff'd, 447 U.S. 74 (1980); Batchelder v. Allied Stores Int'l, 445 N.E.2d 590, 595 (Mass. 1983); New Jersey Coalition Against War in the Middle East v. J.M.B. Realty, 650 A.2d 757, 774-75 (N.J. 1994), rev. denied sub. nom. Short Fills Assoc. v. New Jersey Coalition Against War in the Middle East, 64 U.S.L.W. 3210 (U.S. Oct. 3, 1995); State v. Dameron, 853 P.2d 1285, 1293 (Or. 1993).

67. Hague v. CIO, 307 U.S. 496, 515 (1939) (voiding ordinances restricting public speech and distribution of leaflets but refraining from extending protection to corporation's free speech rights).

68. Curtis J. Berger, Pruneyard Revisited: Political Activity on Private Lands, 66 N.Y.U. L. REv. 633, 674 (1991). 


\section{B. Who Pays?}

In addition to experiencing the loss of rights and privileges entailed in the privatization of public space, nonmembers are frequently compelled to finance their own disentitlement. ${ }^{69}$ The insistence of the homeowners' lobby on receiving public funds that inure to the benefit of purely private streets and tax deductions for association membership fees reveals a desire to share in the common fisc even while retreating from the common space.

\section{The Use of Public Resources}

In general, residential associations all over the country have benefitted from state expenditures on their behalf. Their streets, fire hydrants, street lamps, and other facilities were paved, installed, or constructed at public expense. ${ }^{70}$ The plantations of Hilton Head could never have been built without federal flood insurance, drawn from taxpayers' pockets. ${ }^{71}$ It is far from clear whether associations adequately reimburse state or local governments when they assume control over property. More egregiously, assuming control over property is not always linked to assuming financial responsibility for its maintenance. Some associations, however, do accept this responsibility: Several municipalities, including Houston, Texas, Kansas City, Missouri, and Montgomery County, Maryland, already offer a property tax rebate to reward residential associations for providing their own services. ${ }^{72}$

A recent example of the power of residential associations to claim public funds comes from New Jersey. In early 1993, then-Governor Jim Florio signed the Municipal Services Act, ${ }^{73}$ which requires local governments either to provide private communities with public services, including street sweeping, garbage collection, snow plowing, and street lights, or to reimburse them out of their taxes for what such services cost. ${ }^{74}$ Although the New Jersey Act was passed by the state legislature in $1990,{ }^{75}$ its enactment was delayed by

69. This reveals why "privatization" is an imperfect metaphor for this process. This Note uses the term sparingly.

70. In Citizens Against Gated Enclaves v. Whitley Heights Civic Ass'n, 28 Cal. Rptr. 2d 451, 456 (Ct. App. 1994), for example, the city would have remained responsible for street repairs, maintenance, and services such as lighting and sewage even though the streets would purportedly have been privatized.

71. The General Accounting Office estimates that between 1978 and $1987, \$ 1.1$ billion of tax money was pumped into the Federal Flood Insurance Fund. See Heflin, supra note 44, at 33. Obviously, not all of this money went to Hilton Head.

72. DILGER, supra note 2 , at $28-29$.

73. N.J. STAT. ANN. $\$ \$ 40: 67-23.2$ to $40: 67-28$ (West 1995).

74. Id. $\$ 40: 67-23.3$ (a) provides, "the governing body of every municipality shall reimburse a qualified private community for the following services... or provide the following services within a qualified private community in the same fashion as the municipality provides these services on public roads and streets ...." The statute then goes on to list a host of services, including those enumerated above.

75. The legislation was passed "under pressure from members of community associations who paid both local taxes and the associations' maintenance fees." Schemo, supra note 42, at B6. 
litigation filed by the New Jersey League of Municipalities, which eventually reached a compromise with the New Jersey chapter of the Community Associations Institute in 1992; the end result lowers taxes on unit owners by $\$ 180$ annually. ${ }^{76}$ The Act now specifically exempts from its purview "any road or street ... not accepted for dedication to public use." ${ }^{n 7}$ An association that prevents the public from using streets or other properties, therefore, does not receive any tax reduction. This arrangement is a sensible compromise. However, association advocates are far from satisfied with this result and hope to push the costs of maintaining even private streets onto municipalities. "'Inequities still exist,"” insisted Phyllis Matthey, president of the Coalition of Associations for Political Action, "With this legislation there is hope that these issues can be addressed over time." 78 The stance of the New Jersey associations is clear: Their streets are public for the purpose of getting those services they want yet private for the purpose of excluding those people they do not want. If New Jersey is a typical example, ${ }^{79}$ governments are willing to subsidize the secession of residential streets on the condition that associations grant full access to those streets. However, residential associations are sufficiently powerful that even this condition may be relaxed over time.

In sum, residential associations impose a variety of external costs on neighboring communities. Besides assuming control over facilities created at public expense, associations may also siphon off additional public resources through tax deductions. These costs may be as subtle as a campaign to use public dollars for private streets, as in New Jersey, or as banal as the burdens imposed by one condominium association in New York, whose air-conditioner cooling systems pumped gallons of used water into the streets of the surrounding town. ${ }^{80}$ The weight of these burdens belies the rhetoric of separation.

\section{The Looming Battle over Tax Deductions}

Residential associations generally seek tax status under $\S 528$ of the Internal Revenue Code. Entitled "Certain Homeowners Associations," this provision is "the preferred vehicle for most POA's [Property Owners'

76. Andree Brooks, Condos and Co-ops Ask Equity, N.Y. Times, Dec. 6, 1992, §10, at 5.

77. N.J. STAT. ANN. \$ 40:67-23.3(b) (West 1995). at 9.

78. Rachelle Garbarine, Municipal Services for Condos and Co-ops, N.Y. TIMEs, Jan. 31, 1993, $\$ 10$,

79. The position of the New Jersey associations is similar to the position of some residential associations who have been pushing city governments to assume the costs of municipal services even on private streets. See Citizens Against Gated Enclaves v. Whitley Heights Civic Ass'n, 28 Cal. Rptr. 2d 451, 456 (Ct. App. 1994); Jordan Betz, City Will Consider Taking Over Maintenance of Private Streets, Sr. Louls POST-DisPATCH, Feb. 24, 1994, at 2.

80. See Incorporated Village of Atlantic Beach v. Pebble Cove Homeowners' Ass'n, 527 N.Y.S.2d 429, 429 (App. Div. 1988). The New York appellate court, however, held that the village was not entitled to relief. $I d$. at 430 . 
Associations] seeking tax exemption." ${ }^{\text {81 }}$ Section 528(b) imposes a tax of $30 \%$ on the association's income, but $\S 528(\mathrm{~d})$ (3) allows the exclusion of "exempt function income," meaning "any amount received as membership dues, fees, or assessments" from property owners in the association. ${ }^{82}$ Despite the fact that an association is not taxed on the membership fees it collects, or perhaps because the tax arrangement benefits the association rather than the individual members, one rallying point for homeowners' association advocates has been the proposal that residents be able to deduct these fees much as they deduct state and local taxes. This means that all fees paid by members to increase the value of their property through association-provided improvements would never be taxed at all.

Were association membership fees tax-deductible, the savings to individual members could be considerable. The average mandatory membership fee varies widely. According to a 1989 report, the average annual fee for residential association members was $\$ 867$, but the median annual fee was only $\$ 336{ }^{83}$ In 1992, members of Leisure World, California, paid a flat fee of $\$ 290$ a month, or $\$ 3480$ annually. ${ }^{84}$ In 1989 , homeowners in Ladue, Missouri, paid an annual fee of $\$ 123$ per household and in nearby Olivette, $\$ 67$ annually per household. ${ }^{85}$ These fees are an extra burden on homeowners in addition to property taxes, but it should be recognized that members receive a higher level of goods and services in return. Still, the perception that residential association members pay twice for some services does have some obvious political potential. Executive Council of Home Owners (ECHO) lobbyist Robyn Boyer Stewart writes, "It is only a matter of time before the tax-and-equity bomb blows. ... The politician who manages to capture this constituency, speak to its needs and offer it a voice, will be amply rewarded."'\$6

As every tax deduction is to some degree a subsidy, claimants for a deduction should have to prove both that they are bearing a cost and that there

81. NATELSON, supra note 2 , at 546 . IRS revenue rulings have made it virtually impossible to qualify for the exemption under any other section. See D.K. Campbell-Bell, Homeowners Associations-Is Tax Exemption Worth the Effort?, 20 REAL PROP. PROB. \& TR. J. 647, 659 (1985).

82. I.R.C. $\$ 528($ d)(3) (1988). This is subject to some limitations, however: I.R.C. $\$ 528(c)(1)(B)$ (1988) requires that a homeowners' association receive at least $60 \%$ of its gross income from membership dues to qualify under this section, and I.R.C. $\$ 528(\mathrm{c})(1)(C)$ mandates that "90 percent or more of the expenditures of the organization for the taxable year be expenditures for the acquisition, construction, management, maintenance, and care of association property." These expenditures, of course, increase the value of the property and lay the foundation for future windfalls.

83. ACIR REPORT, supra note 2 , at 11.

84. This money went to services such as the private security force, a television station, and 12 bus routes. Government by the Nice, for the Nice, THE ECONOMIST (London), July 25, 1992, at 25 [hereinafter Government by the Nice].

85. Oakerson, supra note 50 , at 57.

86. Louv, supra note 11, at A2. The first politician to seize upon this issue was none other than the hapless Jimmy Carter, who won the 1975 Florida Democratic primary in part by sending a letter to condominium associations stating that he would abolish certain "unpopular recreation fees" imposed by developers. What Carter as President would be able to do about this issue was never clear. See RICHARD LOUV, AMERICA II, at 110 (1983). 
is greater social utility if government bears the cost in their stead. It is worth asking whether residential associations should enjoy an additional exemption from public responsibility when their expenditures carry no benefits to anyone else. Even if an association assumes the cost of its own upkeep, the municipality's or county's ability to divert funds elsewhere may be more than offset by the loss in tax revenue from often wealthy secessionist enclaves. In addition to the lack of public utility in granting such deductions, offering an exemption makes it even more attractive for homeowner groups to secede. As explained below, there are a variety of reasons why this is undesirable from society's vantage point.

\section{Social Harms}

The most harmful effect of the growth of residential associations may be the widening of the American class divide. Current Labor Secretary Robert Reich calls this effect the "secession of the successful." disengagement of the wealthier and more skilled does not bode well for the ability of the United States to meet future challenges. It also inflicts a number of immediate harms. Increasing social separation and division mean that "life inside and outside of ... [such] communities can represent two different worlds in terms of service levels, citizenship, governance, financial responsibilities, and property rights." ${ }^{98}$ Although discrimination on the basis of class is not unconstitutional per se, ${ }^{89}$ it is worth examining the deleterious impact of wealth differentials and the constitutional questions these disparities may raise.

One especially harmful result of class secession is the diminishing sense of civic responsibility. Particularly insular residential associations foster the perception that "one's duties consist of satisfying one's obligations to private property." 90 This lack of concern for social needs is inevitably reflected in voting behavior. As one commentary puts it, "[]f affluent Americans choose to live in private communities which raise their own taxes but do not redistribute them outside their walls, they are likely to vote to cut spending on public services that they do not use, ignoring the needs of people who cannot afford to go private."11 Mere selfishness obviously does not give rise to a

87. Reich, supra note 29 , at 16.

88. ACIR REPORT, supra note 2, at 13-14.

89. See supra note 39 . Exclusionary zoning may, however, be subjected to constitutional challenges. See Lawrence G. Sager, Ttght Little Islands: Exclusionary Zoning, Equal Protection, and the Indigent, 21 STAN. L. REV. 767 (1969). But see Reichman, supra note 2, at 301-04 (arguing that restrictions on use of exclusionary zoning should not apply to servitudes governing residential associations).

90. MCKENZIE, supra note 2, at 196.

91. Government by the Nice, supra note 84 , at 26 . In other words, “[i]f we're already paying for our own private services, why should we pay for someone else's police or recreation centers or libraries?" Louv, supra note 11, at A2. Or, as a more gentle source puts it, association residents "may be inclined to vote differently on tax and service issues." ACIR REPORT, supra note 2, at 6. 
constitutional cause of action. Yet the consequent wealth disparities may create contentious social and legal issues such as the school-financing scheme that was at issue in San Antonio Independent School District v. Rodriguez. ${ }^{92}$ Not all courts, moreover, are wary of engaging these issues. In New Jersey, for example, a "holy trinity" of cases established that all municipalities and localities in a given area must share responsibility for the "general welfare" of their region in meeting its need for low-income housing. ${ }^{94}$ Furthermore, the secession of the successful promises to have a critical impact on social policies that may eventually wind up in court.

Even if some exclusive associations never see the inside of a courtroom, however, their separatism may still have pernicious social effects. As urban sociologist Jane Jacobs characterizes the problem, "It's a gang way of looking at life, an institutionalization of turf. And if it goes on indefinitely, and gets intensified, it practically means the end of civilization.",95

\section{RESIDENTIAL ASSOCIATIONS AS STATE ACTORS}

The preceding sections have argued that residential associations impose a number of negative externalities on the communities that surround them. These negative impacts, moreover, stem from the nature of associations as virtual governments: They exercise dominion over streets and thoroughfares; pass rules to regulate access and speech; and employ security personnel to keep the peace. This part will argue first that the law currently does not adequately deal with these negative impacts. It will then demonstrate that the functions served by associations and their interdependent relationships with local governments transform their basic nature from private to public, such that they should be regarded as state actors. It is a truism that the Fourteenth Amendment "erects no shield against merely private conduct, however discriminatory or wrongful." 96 Before an aggrieved plaintiff rnay invoke rights guaranteed by the Constitution, "it is essential to establish that the State . . . is responsible for the infringement." 97 Yet the distinction between public and private does not

92. 411 U.S. 1 (1973).

93. Ford, supra note 40 , at 1897.

94. These cases are Southern Burlington County NAACP v. Township of Mount Laurel, 336 A.2d 713 (N.J.) (requiring that municipality's land-use regulation take account of needs of low- and moderate-income individuals), cert. denied, 423 U.S. 808 (1975); Southern Burlington County NAACP v. Township of Mount Laurel, 456 A.2d 390 (N.J. 1983) (striking down ordinance on ground that it did not provide for needs of low-income individuals); and Hills Dev. Co. v. Township of Bernards, 510 A.2d 621 (N.J. 1986) (pronouncing New Jersey Fair Housing Act constitutional and announcing court's withdrawal from issue).

95. Dillon, supra note 30 , at 10 . Rice University sociologist Stephen Klineberg concurs: "'If I'm making it, it's not my responsibility to look after others. That's the direction American society seems to be going, and it's ominous. It will destroy us in the end." Id.

96. Shelley v. Kraemer, 334 U.S. 1, 13 (1948) (holding that state enforcement of private housing covenants requiring racial discrimination was unconstitutional state action).

97. Daphne Barak-Erez, A State Action Doctrine for an Age of Privatization, 45 SYRACUSE L. REv. 1169,1171 (1995) (arguing that extent of privatization requires expansion of state action doctrine). 
preclude judicial consideration of the discriminatory conduct of putatively private entities that rely on state power and privileges. When ostensibly private conduct takes on a public character, that conduct may be reached through the application of the state action doctrine.

\section{A. Current Judicial Responses}

\section{Reasonableness for Members}

One way courts might limit the power of residential associations would be to ask whether the restriction in question is "reasonable"; if not, the restriction would be invalidated. This is the standard most courts have used when disgruntled residents have challenged their own association's rules. Because the restrictions residents object to are usually in the membership contracts they signed, most courts have asked only whether the rule in question comports with a standard of "reasonableness,"98 thereby upholding restrictions on age, ${ }^{99}$ the presence of pets, ${ }^{100}$ and the disposition of property. ${ }^{101}$ The "reasonableness" standard is frequently established by legislatures ${ }^{102}$ and derives largely from the law of servitudes. ${ }^{103}$ At the root of the presumption of legitimacy accorded an association's CC\&Rs is consent. Residents who complain about any provision of the association's CC\&Rs or bylaws must counter the argument that they read these restrictions, considered them, and signed anyway. In contrast to one's membership in the broader society, it is

98. Gregory S. Alexander, Dilemmas of Group Autonomy: Residential Associations and Community, 75 CORNELL L. REV. 1, 12-17 (1989). A minority of jurisdictions, including New York, employ a "business judgment" standard. For a comparison of the two standards, see Kress, supra note 4, at 863-69.

99. See, e.g., Riley v. Stoves, 526 P.2d 747 (Ariz. Ct. App. 1974) (upholding age restriction even while finding residential association policy constituted state action); O'Connor v. Village Green Owners Ass'n, 183 Cal. Rptr. 111 (Ct. App. 1982) (upholding rule limiting occupancy to persons over age eighteen). But see, e.g., Park Redlands Covenant Control Comm. v. Simon, 226 Cal. Rptr. 199 (Ct. App. 1986) (holding that age restrictions of CC\&Rs violated Unruh Civil Rights Act).

100. See, e.g., Nahrstedt v. Lakeside Village Condominium Ass'n, 878 P.2d 1275 (Cal. 1994) (upholding rule banning pets such as cats and dogs from condominium association as "reasonable" under California Civil Code \$ 1354); Dulaney Towers Maintenance Corp. v. O'Brey, 418 A.2d 1233 (Md. Ct. Spec. App. 1980) (sustaining rule prohibiting ownership of too many pets). But see, e.g., Chateau Village N. Condominium Ass'n v. Jordan, 643 P.2d 791 (Colo. Ct. App. 1982) (refusing to allow association to apply policy prohibiting additional pets without association's reasonable consideration of request for exemption).

101. See, e.g., Amoco Realty Co. v. Montalbano, 478 N.E.2d 860 (Ill. App. Ct. 1985) (upholding restriction against use of property for business purposes).

102. CAL. CIV. CODE $\$ 1354$ (West Supp. 1995), for example, provides: "The covenants and restrictions in the declaration shall be enforceable equitable servitudes, unless unreasonable, and shall inure to the benefit of and bind all owners of separate interests in the development." FLA. STAT. ch. 718.112(3) (1977) allows a number of restrictions that the Florida Supreme Court interpreted as "reasonable restrictions" in White Egret Condominium, Inc. v. Franklin, 379 So. 2d 346, 350 (Fla. 1979).

103. See NATELSON, supra note 2, at 48-55. Natelson notes, however, that the relationship is imperfect since under the law of servitudes, covenants must "run with the land," whereas residential associations frequently provide a broader range of services and insist on a variety of rules that do not touch or concern the land per se. Id. at 50 . 
asserted, one's membership in an association may be regarded as "wholly voluntary." 104 Despite the low standard of review, even the "reasonableness" test has been objected to as impermissible interference with contractual freedom, on the grounds that the only appropriate review of the rule in question is that performed by the homeowner as he or she signs the contract. $^{105}$

Resolving the disagreements between associations and their members is not the object of this Note. ${ }^{106}$ Yet the hotly contested disputes ${ }^{107}$ over the allocation of responsibilities between associations and their members suggests the limited usefulness of the "reasonableness" test as a possible tool in allocating responsibility between associations and the larger polity. Even if it were clear that all residents had explicitly consented to the CC\&Rs or other bylaws governing their associations, nonmembers simply have no privity of contract with the associations. Although it is currently the major focus of residential association jurisprudence, the "reasonableness" standard rests on premises foreign to the nature of the relationship between associations and nonmembers. While a sensible inquiry can be made as to whether a contractual agreement is "reasonable," how can a court decide whether it is "reasonable" to discriminate or exclude without reference to constitutional standards? Far from triggering even "reasonableness" as a pretext for judicial activism, however, these harms have been largely ignored.

104. Ellickson, supra note 6, at 1523. But see NATELSON, supra note 2, at $490 \mathrm{n} .9$ (arguing that Ellickson "substantially understates the practical distinctions" between cities and homeowners' associations).

105. Ellickson derides the "reasonableness" test as "an apparent invitiation [sic] to Lochnerian activism." Ellickson, supra note 6, at 1526. This invitation, however, has not been accepted by the courts. See supra notes $98-102$.

106. It should be noted, however, that the contractual approach makes several questionable assumptions and is limited in its applicability. First, some critics maintain that it is unrealistic to assert that membership in the association is "perfectly voluntary" as all sorts of social forces influence one's choices, from the availability of property and its cost to one's preferences about neighbors. See Ford, supra note 40 , at 1883-85. Hence associations simply cannot be viewed "as a miniature version of the liberal society envisioned by John Locke." Frug, supra note 6, at 1589. Proponents of consent-based theories often fall victim to what has been called "the tautology of community self-definition" because "although the governance of such an association may be democratic in form, it may well not be democratic ... in substance if the initial selection of members was highly exclusive." Ford, supra note 40, at 1860. For a more extensive discussion of the coercive nature of residential associations, see Gregory S. Alexander, Freedom, Coercion, and the Law of Servitudes, 73 CORNELL L. REv. 883 (1988).

Second, some measure of coercion is inescapable given the sheer impossibility that the prospective homeowner is able to veto a provision of the CC\&Rs he or she might not like. Hence the idea that owners agree to all preexisting servitudes has been called "a controversial one." Natelson, supra note 32, at 54. In fact, "many home buyers do not read or fully understand the neighborhood's CC\&Rs prior to purchasing their homes." DILGER, supra note 2, at 35. These objections, however, have not received a warm reception in state courts. The prevalence of the "reasonableness" standard seems to foreclose searching inquiry into the legitimacy of the residential associations' CC\&Rs.

107. See, e.g., Associate Justice Kaufman's nasty concurrence in Park Redlands Covenant Control Commission v. Simon, 226 Cal. Rptr. 199, 207 (Ct. App. 1986):

Finally, while I am bound by the decisions of the California Supreme Court prohibiting age discrimination in housing, I find those decisions legally and practically inane. . . . The rights [of freedom of association] overlooked are at least as significant and as sacrosanct as the rights of those for whom our high court in its paternalistic wisdom is so solicitous. 
In short, "reasonableness" poses an unacceptably vague question about the negative externalities of associations on nonmembers and falls far below guaranteeing the adherence to constitutional standards we should demand of public bodies.

\section{Blocking the Transfer of Authority}

A second way that courts might limit the power of residential associations would be to disallow any transfer of authority from adjacent local governments to associations, or at least to impose limitations on such transfers. As the latter route seems to require a high degree of judicial activism, only the former has been pursued, and even then only rarely. Although preventing the diminution of public space is a laudable goal, refusing to allow a state or local government to invest any power in a residential association fails to account for the ways in which the association could benefit the larger community. This argument will be addressed more thoroughly below. ${ }^{108}$ For now, it is worth noting the inherent problems in blocking all delegations of authority from governments to associations.

The recent Whitley Heights case provides a clear example of a court choosing to prevent the transfer of authority to an association. ${ }^{109}$ In granting an injunction requested by Citizens Against Gated Enclaves, a California Court of Appeal emphasized that the public trust invested in the streets precluded their privatization: "'The streets of a city belong to the people of the state, and the use thereof is an inalienable right of every citizen." "'[a] street may not be vacated for exclusive private use." "111 This Note shares the basic concerns of the Whitley Heights court. However, this Note departs from the court's approach for two reasons. The decision in Whitley Heights is problematic insofar as it precludes the mere existence of associations. As explained more fully in the following sections, the preferable solution to the problematic relationship between associations and the public at large is cohabitation, not complete denial of association members' rights to freedom of association. A more technical problem with the decision in Whitley Heights is that the court rested its argument not on a provision of the California Constitution but on its Vehicle Code, ${ }^{112}$ far too narrow a tool to limit the harms to public rights. What the decision leaves open, therefore, is

108. See infra Subsection III.B.3.

109. See supra text accompanying notes 54-57.

110. Citizens Against Gated Enclaves v. Whitley Heights Civic Ass'n, 28 Cal. Rptr. 2d 451, 454 (Ct. App. 1994) (quoting City of Lafayette v. County of Contra Costa, 154 Cal. Rptr. 374, 376 (1979) (overruling Lafayette City Council's decision to close off particularly congested street)).

111. Id. at 455 (quoting Constantine v. City of Sunnyvale, 91 Cal. App. 2d 278, 282 (1949)).

112. Specifically, a section of the code states that, "local authorities may not place gates or other selective devices on any street which deny or restrict the access of certain members of the public to the street."' Id. at 453 (quoting CAL. VEH. CODE $\S 21101.6$ (West Supp. 1995)). 
the question of whether the transfer of authority from government to association endows the latter with the status of a state actor. The next section will argue that it does.

\section{B. State Action}

The state action doctrine provides a means of applying constitutional guarantees and restrictions to private conduct when that conduct is so entangled with public authority that it cannot be considered purely private. This doctrine is necessary to prevent an individual or association, clothed in the mantle of private conduct, from injuring others through the exercise of state power. Once regarded as a "conceptual disaster area," has more recently been considerably yet imperfectly narrowed. ${ }^{114}$ Although far from crystal clear, the state action doctrine best captures the nature of the power entrusted to residential associations. ${ }^{115}$ It offers an alternative means of examining the behavior of associations apart from the presumption of contractual legitimacy, an alternative that is vital to begin to address the burdens residential associations impose on nonmembers. Hence this section will argue that courts should subject plaintiffs challenging residential association authority to a status analysis: With respect to claims made by nonmembers, residential associations should be treated as state actors, assuming the facts warrant such a finding. ${ }^{116}$ With respect to claims made

113. Charles L. Black, Jr., The Supreme Court, 1966 Term-Foreword: "State Action," Equal Protection, and California's Proposition 14, 81 HARV. L. REV. 69, 95 (1967).

114. It is now showing renewed signs of expansion, however, following the decline of the approach taken by Chief Justice Rehnquist, who would almost uniformly deny the presence of state action. See Henry C. Strickland, The State Action Doctrine and the Rehnquist Court, 18 HASTINGS CONST. L.Q. 587, 643-66 (1991).

115. As well as the abuse of this power: One journalist notes that for residential associations, "in place of municipal rules are a set of regulations so restrictive that many could be found unconstitutional should a city government enact them." Egan, supra note 22, at A1. There was some discussion of treating residential associations as state actors with respect to internal voting procedures at the dawn of associations' popularity. See, e.g., Comment, Democracy in the New Towns: The Limits of Private Government, $36 \mathrm{U}$. CHI. L. REV. 379 (1969) (arguing that residential associations are sufficiently like municipalities that they should comply with principle of one person, one vote); Note, New Community Development, 11 WASHBURN L.J. 227 (1972) (same). A few more recent commentators echo this suggestion. See, e.g., DILGER, supra note 2 , at $142-44,160$.

116. This argument is very different in several critical respects from that presented in Brian $L$. Weakland, Condominium Associations: Living Under the Due Process Shadow, 13 PEPP. L. REV. 297, 327-30 (1986). While Weakland also proposes a two-part test that would find state action or employ a reasonableness standard, his does not distinguish between members and nonmembers. In doing so, Weakland ignores the important difference in status between nonmembers and members; his thesis is therefore seriously vulnerable to a consent-based argument that members are differently situated than nonmembers by having agreed to the restrictions they now challenge.

More fundamentally, Weakland proposes that associations should not be subject to a state action test "so long as [the association] acts within the powers codified by state statute." Id. at 330-31. But this is backwards. It is precisely when a municipality or state has delegated a share of its power to an association or individual that the latter is most clearly a state actor. See, e.g., Edmonson v. Leesville Concrete Co., 500 U.S. 614, 616 (1991) (holding that private party's use of peremptory challenges to exclude black juror 
by members, so long as prior consent was given to the restrictions or rules in question, the "reasonableness" test will apply. 117

Advocating the application of the state action framework to residential associations does not imply that every residential association is a state actor: The test for state action is fundamentally a fact-bound determination, requiring examination of a wide variety of linkages between the actor and state authority. ${ }^{118}$ The likelihood that an association will be deemed a state actor is closely linked to the impact that it has upon the surrounding community. Associations that gate vast expanses of public streets and consume significant governmental resources will create stronger presumptions of state action than groups of homeowners who simply band together and agree to paint their houses chartreuse.

The state action doctrine has assumed a variety of forms over the past half century. In 1982, the Supreme Court attempted to unify the various strands of the doctrine by developing a two-prong test in Lugar v. Edmondson Oil Co. ${ }^{119}$ This test required that:

First, the deprivation must be caused by the exercise of some right or privilege created by the State or by a rule of conduct imposed by the State or by a person for whom the State is responsible. . . . Second, the party charged with the deprivation must be a person who may fairly be said to be a state actor. ${ }^{20}$

Unfortunately, the Court did not apply this test prong-by-prong to the facts at issue, instead grounding its finding of state action in the "joint participation" between the private party and the government. ${ }^{121}$ Nor has the Court followed

would constitute impermissible state action); Lugar v. Edmondson Oil Co., 457 U.S. 922, 935 (1982) (holding that ex parte pretrial attachment order constituted state action violating due process).

117. One immediate and pertinent objection to this approach is that the distinction between members and nonmembers is not so clear as to presume that a status distinction can be made. After all, perhaps the most potent means of discrimination is the ability to create barriers to entry that prevent nonmembers from ever becoming members. Additionally, it is a valid question whether renters of property in the district should properly be considered members or nonmembers. These individuals "are often purposively disenfranchised ... because they have an incentive to oppose efforts to increase the neighborhood's property values." DILGER, supra note 2, at 34. The two-tier level of review advanced by this Note, one which treats nonmembers differently than members, is a compromise between reality and theory. Most case law follows a predictable pattern. People move in and sign the CC\&Rs; they violate the rules; the association sues for compliance; the court enforces compliance. Generally, residential associations should be understood to be state actors. The contract between association and resident, however, trumps this principle in practice and thus necessitates a two-tier level of review.

118. One frequently cited guide to the application of the doctrine remarks, "Only by sifting facts and weighing circumstances can the nonobvious involvement of the State in private conduct be attributed its true significance." Burton v. Wilmington Parking Auth., 365 U.S. 715, 722 (1961) (holding coffee shop's exclusion of blacks to be impermissible state action as shop was located in municipal building).

119. 457 U.S. 922 (1982) (holding that ex parte pretrial attachment order constituted state action violating due process).

120. Id. at 937.

121. Id. at 942 . 
this test in a consistent fashion since, ${ }^{122}$ although some circuit courts have done so. ${ }^{123}$ Instead, the Court has applied a variety of gestalt tests capturing the essence of Lugar's two prongs. Various forms of the state action test seek to determine whether there is overt action by the state, state enforcement of state law, denial of relief by the state, the performance of a public or governmental function by a private entity, or joint participation by or a symbiotic relationship between the private actor and the state. ${ }^{124}$ Fully understanding the extent of the applicability of the state action doctrine to residential associations requires analyzing the two formulations of the state action test most relevant in this context: whether a "symbiotic relationship" exists between a nominally private entity and the state; or whether the nominally private entity serves a "public function." 125

State courts have reached wildly different conclusions when faced with the argument that a residential association qualifies as a state actor. Finding that "[a] homeowners" association lacks the municipal character of a company town,"126 a Florida District Court of Appeal held in 1987 that a homeowners' association in a mobile home park was not a state actor. In the 1982 California case requiring a residential association to grant equal access to an outside newspaper, by contrast, a California Court of Appeal remarked that the association "in many respects does display many of the attributes of a municipality." 127 Finally, an Arizona Court of Appeals held that while a residential association was a state actor, its age-restrictive covenants did not amount to impermissible discrimination. ${ }^{128}$ While the following discussion will clarify the doctrinal issues, it should be kept in mind that the state action test is so acutely sensitive to factual determinations that these seemingly

122. Although Edmonson v. Leesville Concrete Co., 500 U.S. 614, 618-28 (1991) (holding that private party's use of peremptory challenges to exclude black juror would constitute inadmissible state action) applied the Lugar test prong by prong, the Court in Tulsa Professional Collection Services v. Pope, 485 U.S. 478 (1988) (holding that due process prevented nonclaim statute from starting to run before reasonably ascertainable creditors had been notified) collapsed the test to hold simply that "pervasive and substantial" state involvement constituted state action. Id. at 487.

123. See, e.g., the Tenth Circuit's step-by-step application of the Lugar test in Gilmore v. Salt Lake Community Action Program, 710 F.2d 632, 637-39 (10th Cir. 1983) (maintaining that while community action agency was state actor, dismissal of its former director was not state action).

124. See Strickland, supra note 114, at 596-634.

125. Katharine Rosenberry divides her analysis this way as well, as these are the only two applicable forms of the state action test. See Katharine Rosenberry, The Application of the Federal and State Constitutions to Condominiums, Cooperatives and Planned Developments, 19 REAL PROP. PROB. \& TR. J. 1, 11-25 (1984) [hereinafter Rosenberry, Application of the Federal and State Constitutions]. The phrase "symbiotic relationship" first appeared in Moose Lodge No. 107 v. Irvis, 407 U.S. 163, 175 (1972) (holding that state's grant of liquor license to club with racially discriminatory admissions policy did not constitute state action). The phrase "public function" comes from Marsh v. Alabama, 326 U.S. 501, 506 (1946) (holding that company-owned town's prohibition on distribution of literature by Jehovah's Witness constituted impermissible state action).

126. Brock v. Watergate Mobile Home Park Ass'n, 502 So. 2d 1380, 1382 (Fla. Dist. Ct. App. 1987).

127. Laguna Publishing Co. v. Golden Rain Found., 182 Cal. Rptr. 813, 827 (Ct. App.), appeal dismissed for want of a substantial federal question, 459 U.S. 1192 (1982).

128. See Riley v. Stoves, 526 P.2d 747, 751-54 (Ariz. Ct. App. 1974). 
contradictory decisions could be reconciled on the grounds that they involved different relationships between the private entity and the state or differences in the egregiousness of the discriminatory conduct at issue.

\section{The "Symbiotic Relationship" Test}

The "symbiotic relationship" criterion originated in the 1961 case of Burton v. Wilmington Parking Authority, ${ }^{129}$ in which the Court found that a coffee shop operator who refused to serve black customers was a state actor by virtue of renting space from the State of Delaware in a public building alongside municipal offices and adjoining a municipal parking lot. Yet the criteria for determining whether the nature of the relationship with the state transforms the private entity into a state actor have become far more stringent since Burton; it is likely that the facts of Burton would not pass muster under the rule developed in its progeny. ${ }^{130}$ In Rendell-Baker $v$. Kohn, ${ }^{131}$ for example, a seven-member majority of the Court refused to find state action even though the putative state actor was a school for wayward high school students, nearly all of whom were referred from public schools. Furthermore, the school complied with a variety of state regulations and received more than ninety percent of its budget from the state. ${ }^{132}$

Under the "symbiotic relationship" test, a court must examine "the extent to which the actor relies on governmental assistance and benefits" and "whether the injury caused is aggravated in a unique way by the incidents of governmental authority."133 The Supreme Court has made clear that the interrelationship between the private actor and the state must be significant to meet this standard: A private party does not become a state actor by the mere fact that "the private entity receives any sort of benefit or service at all from the State, or if it is subject to state regulation in any degree whatever."134

In general, residential associations should qualify as state actors under this formulation of the state action test. With respect to the first prong of the test, the state participates in the act of creating a residential association by ceding some of its authority to the association, which in many cases is the sine qua non of the association's existence. If one crucial element of the association's authority is private control over once-public streets, this control can be granted only at the initial expense of, and with the cooperation of, the state.

129. 365 U.S. 715, 723-25 (1961). Note that the phrase does not actually appear in Burton, but in a subsequent decision characterizing the case. See supra note 125.

130. See, e.g., Blum v. Yaretsky, 457 U.S. 991, 1010 (1982) (rejecting Burton-based argument as "vague generalization").

131. 457 U.S. 830 (1982).

132. Id. at 832-33.

133. Edmonson v. Leesville Concrete Co., 500 U.S. 614, 622 (1991) (citing Shelley v. Kraemer, 334 U.S. 1 (1948)).

134. Moose Lodge No. 107 v. Irvis, 407 U.S. 163, 173 (1972). 
This level of state authority, moreover, implicates governmental power when the delegated authority is used to exclude or discriminate. In some cases, the state essentially collaborates with private developers to produce precisely such a discriminatory result, hoping to use the private entity as a shield. A clear case involving collusion between a homeowners' association and a governmental authority is Park Redlands Covenant Control Commission $v$. Simon. ${ }^{135}$ In that case, the municipal authorities struck a deal with a developer by which the latter would impose minimum-age and maximumnumber restrictions on occupancy. As such regulations would violate California's Civil Rights Act, the city clearly hoped to "take refuge in the private party status of the developer." 136 The city even retained the power to approve any further changes to the restrictions on age and occupancy. ${ }^{137} \mathrm{~A}$ California Court of Appeal angrily objected that it "[would] not, ostrich-like, ignore the heavy-handed role played by the City of Redlands in (1) creating, and (2) continuing the existence of this 'purely private' restriction." 138 The result in Redlands refutes the argument that in order for state action to be present, the property must be virtually identical in nature to the company town in Marsh, ${ }^{139}$ and it illustrates how a finding of state action may rely more on the egregiousness of discriminatory intent than on the extent of the relationship between the private entity and the state. Furthermore, Redlands suggests that state action may exist in only one aspect of an association's activities, if that aspect raises constitutionally relevant questions.

With respect to the second prong of the "symbiotic relationship" test, the harms described in the first part of this Note could not occur but for the authority of the state. As "essentially private conduct dependent on state implementation," "140 the behavior that causes these harms constitutes state action. Every major component of an association's power, particularly its authority over once-public streets, relies upon an affirmative decision made by the state to delegate this power to a quasi-governmental organization. State involvement is implicated in the frequent enforcement by the state of the association's governing documents, including assessments, transfer of common areas, meeting times and places, voting rights, elections of the governing body,

135. 226 Cal. Rptr. 199 (Ct. App. 1986).

136. Id. at 206.

137. Id.

138. $I d$.

139. An argument made in Rosenberry, Application of the Federal and State Constitutions, supra note 125 , at 25 .

140. Laguna Publishing Co. v. Golden Rain Found., 182 Cal. Rptr. 813, 828 (Ct. App.) (citing Evans v. Newton, 382 U.S. 296 (1966) (holding that reservation of private park for whites only as per donor's wishes was impermissible state action); Robinson v. Florida, 378 U.S. 153 (1964) (holding that state health board regulation discouraging restaurant service of blacks and whites together was impermissible state action); Anderson v. Martin, 375 U.S. 399 (1964) (striking down Louisiana statute requiring indication of candidate's race on ballot as impermissible state action); and Terry v. Adams, 345 U.S. 461 (1953) (holding that all-white primary that selected candidates for uncontested general election was state action)), appeal dismissed for want of a substantial federal question, 459 U.S. 1192 (1982). 
and budgeting. ${ }^{141}$ This is not to say that the mere existence of the state as an enforcement mechanism is sufficient to meet this part of the state action test. It is important not to press this point so far as to eliminate the distinction between public and private, since "state action, in the form of state law, is present in all legal relationships among private persons." 142 A Maryland appellate court, however, found state action in the enforcement of condominium lien laws because the state participated in the enforcement of these rules. ${ }^{143}$ The U.S. Supreme Court employed a similar rationale in 1988 in Tulsa Professional Collection Services v. Pope ${ }^{144}$ in which it held that the state's participation in activating and enforcing a nonclaim statute gave rise to a violation of due process by a collection agency. Hence interdependence arises when the private entity takes an unconstitutional action and relies upon the state to effectuate that action. As a California Court of Appeal noted in Laguna, state action is present "where there is actual or even threatened enforcement by state law in aid of discriminatory conduct."145 Insofar as the state makes a positive choice to grant an association authority with the knowledge that this authority will be used for discriminatory purposes, that association may be regarded as a state actor under this understanding of the "symbiotic relationship" test.

\section{The "Public Function" Test}

Failure to meet the requirements of the "symbiotic relationship" test does not mark the end of the judicial inquiry. A nominally private entity may also be considered a state actor if it is found to serve a "public function." As with the "symbiotic relationship" approach, this phrase must be interpreted strictly; a private entity does not qualify under the "public function" test merely by serving the public, ${ }^{146}$ it must perform a function "traditionally the exclusive

141. See Rosenberry, Application of the Federal and State Constitutions, supra note 125, at 12. Note that Rosenberry lists these items as matters regulated by the California Department of Real Estate; she does not believe that the enforcement of this extensive set of agreements would amount to state action. Id.

142. Harold W. Horowitz \& Kenneth L. Karst, The Proposition Fourteen Cases: Justice in Search of a Justification, 14 UCLA L. REv. 37, 45 (1966). This argument should not be taken to mean, for example, that the existence of a contract between an association and a member gives rise to state action simply because one party may call the state for enforcement in the event of a breach.

143. See Surfside 84 Condominium Council of Unit Owners v. Mullen (Chy. Case No. 13,915, Md. Cir. Ct. Worcester County, Feb. 27, 1984) (unpublished decision) discussed in Golden Sands Club Condominium v. Waller, 545 A.2d 1332, 1336 n.5 (Md. 1988) (noting that Surfside 84 decision had prompted legislature to revise law in question).

144. 485 U.S. 478 (1988).

145. Laguna Publishing Co. v. Golden Rain Found., 182 Cal. Rptr. 813, 827 (Ct. App.) (emphasis omitted), appeal dismissed for want of a substantial federal question, 459 U.S. 1192 (1982).

146. See, e.g., San Francisco Arts \& Athletics v. United States Olympic Comm., 483 U.S. 522 (1987) (holding that organization promoting amateur sports was not state actor because neither conduct nor coordination of sports was traditional governmental function). 
prerogative of the State." 147 Hence the function performed must involve "some power delegated to [the private entity] by the State which is traditionally associated with sovereignty, such as eminent domain." ${ }^{148}$ The most recent interpretation of this test emphasized determining "whether the actor is performing a traditional governmental function."149

A strong case can be made that residential associations qualify as state actors under the public function test. Robert Natelson, author of the leading textbook on homeowners' associations, argues that public law ought not apply to associations and disparages the analogy between associations and governments, citing "their narrow range of functions, at least compared to general governments; and the absence of the redistributive, police, conscriptive, general welfare taxation, and enforcement privileges characteristic of sovereign power." 150 But police and revenue-raising functions are in fact quite prominent activities of residential associations. As one recent account notes, "They collect taxes and provide public services, including police protection, street cleaning, snow removal, trash collection and park administration. They enforce their detailed codes of behavior and property maintenance through fines and liens on residents' homes." 151 It is hard to see how the issue of governmental reimbursement of associations for performance of municipal services could engender such controversy ${ }^{152}$ unless the services provided by these associations were extensive.

Many services performed by these associations are similar to those performed by local governments. ${ }^{153}$ Dominion over the streets is the most obvious example of authority traditionally associated with the state. Some of the supplementary services fall into this category as well. Articulating the range of "traditional government functions" in the 1976 case of National League of Cities v. Usery, Justice Rehnquist listed "fire prevention, police protection, sanitation, public health, and parks and recreation.... [I]t is functions such as these which governments are created to provide...."154 The only difference between government property and services and those of an association is the association's attempt to privatize these services. One

147. Jackson v. Metropolitan Edison Co., 419 U.S. 345, 353 (1974) (holding that electric company's termination of service upon nonpayment of bills did not violate due process as company was not state actor).

148. Id.

149. Edmonson v. Leesville Concrete Co., 500 U.S. 614, 621 (1991).

150. Natelson, supra note 32 , at 49.

151. Evan McKenzie, When Your Home Is Mostly Other People's Castle, Plain DEALER, Aug. 19, 1994 , at 11B.

152. See supra Subsection II.B.2.

153. Thereby creating obvious parallels to the company town in Marsh v. Alabama, 326 U.S. 501 (1946). See also Garner v. Louisiana, 368 U.S. 157, 181 (1961) (Douglas, J., concurring) (citing Marsh, 326 U.S. 501) ("Towns, though wholly owned by private interests, perform municipal functions and are held to the same constitutional requirements as ordinary municipalities.").

154. 426 U.S. 833, 852, 851 (1976), overruled by Garcia v. San Antonio Metro. Transit Auth., 469 U.S. 528 (1985). 
guide to tax exemptions for residential associations admits the public character of the property and services provided by associations. It explains, "Property traditionally recognized and accepted as governmental in nature (e.g. roadways, park lands, sidewalks, street lights, and firehouses) may also qualify as association property." 155 Yet the constraints placed upon state actors are intended to forestall the assumption of control over these functions of local government without the acceptance of concomitant responsibilities. If residential associations are able to exercise the powers associated with serving a public function, they must also shoulder the responsibilities.

Finally, at common law, performance of the functions today served by residential associations justified treating private individuals as state actors. As the U.S. Supreme Court noted in the 1876 case of Munn v. Illinois, "Looking, then, to the common law ... we find that when private property is 'affected with a public interest, it ceases to be juris privati only."156 Seven years later, Justice Harlan, in his dissenting opinion in The Civil Rights Cases, ${ }^{157}$ would have upheld the 1875 Civil Rights Act as applied to common carriers because owners and operators of private thoroughfares, inns, and parks at common law were treated as essentially state actors because of the public function they performed. ${ }^{158}$ The fact that owners of private roads used by the public on occasion were viewed as state actors has two implications. First, mere private ownership by contemporary residential associations cannot convert formerly public streets and parks into private property. Second, a private person who is the owner or even administrator of a street or park is properly regarded as a state actor because of the public function he or she performs.

\section{The Impact of Treating Residential Associations as State Actors}

The argument advanced by this Note is intended to prevent residential associations from assuming governmental authority without governmental responsibilities, and to make clear the public interest invested in the behavior of putatively private associations. As residential associations have heretofore enjoyed largely free rein, much of what follows is necessarily somewhat speculative. The expected impacts of the suggestions in this Note are twofold. First, treating residential associations as state actors should require residential associations to assume a higher level of responsibility to the public, following the principle that, "[w] here an organization is quasi-public, its power to exclude must be reasonably and lawfully exercised in furtherance of the public

155. Campbell-Bell, supra note 81 , at 651 .

156. 94 U.S. 113, 125-26 (1876) (upholding Illinois legislature's regulation of charges for use of grain elevators).

157. 109 U.S. 3 (1883).

158. Id. at $37-43$ (Harlan, J., dissenting). 
welfare related to its public characteristics."159 This increased responsibility could of course have the effect of discouraging the formation of residential associations. Second, treating residential associations as state actors should require associations to choose between serving as public or private entities, resolving a confusion over role that associations currently manipulate to great advantage. In general, the expected result of the recommendations advanced by this Note would be a halt to the privatization of public space to the degree that such privatization is harmful to those who do not, or cannot, share in the privileges of membership. For example, nothing would prevent an association from hiring security guards so long as those guards did not attempt to force innocent pedestrians out of the neighborhood. Nor would the argument presented in this Note prevent an association from collecting membership dues to ensure that its streets were clean or well lit so long as other members of the public could use those streets as well.

Applying the state action test to evaluate the impact of an association's behavior on nonmembers should not be confused with applying the state action test to police relations between associations and their members. ${ }^{160}$ As discussed above, the principle of reasonableness is a powerful limiting force on the remedies available to members who challenge a residential association's policies. This principle, however, fails to provide meaningful guidance in the cases this Note is concerned about: conflicts between associations and nonmembers. Furthermore, applying the state action test does not mean that every harm described in the preceding sections of this Note can be limited. If, for example, a residential association is considered a virtual government and fulfills its responsibilities as such, there is no reason why members should not be able to receive tax deductions for their association membership fees. This benefit, however, comes with the responsibilities borne by government, most importantly, compliance with the constitutional standards of equal protection and due process. Application of the state action test is not intended to eliminate the power of residential associations but simply to match this power with appropriate responsibilities.

The first important effect of treating residential associations as state actors would be that constitutional obligations would trump the associations' covenants and practices with respect to nonmembers. ${ }^{161}$ As discussed in Part II, the treatment residential associations frequently accord nonmembers raises a host of constitutional concerns, including limitations on First Amendment

159. Matthews v. Bay Head Improvement Ass'n, 471 A.2d 355, 366, 368 (N.J. 1984) (recognizing public trust invested in tidal lands and consequent obligation of homeowners' association to keep beaches open to public). The association in this case benefitted from the municipality's free capital improvements, office space, and tax exemptions. Id. at 367-68.

160. One strong advocate of residential associations rejects the state action test altogether on the assumption that it would have to apply to relations between the association and its members. See Rosenberry, Application of the State and Federal Constitutions, supra note 125, at 28-31.

161. With respect to members, the CC\&Rs would likely remain dispositive. See supra note 117. 
rights to freedom of speech and association; the right to travel; due process issues raised by the application of an association's rules to nonmembers; and equal protection questions raised by discrimination on the basis of race or class. These concerns arise in different contexts, including the initial development of the property, the use by nonmembers of an association's streets or other properties, and the use of public funds as a subsidy for one neighborhood but not another. ${ }^{162}$ Nonmembers would be able to challenge existing practices with discriminatory effects on constitutional grounds in addition to bringing suits to impede the transfer of authority from a local government to a residential association, the option currently available. For example, an individual belonging to a minority group who is denied access to the city blocks comprising a particular association, or who is roughed up by a security guard, would be able to bring an action against the association for discrimination and damages.

This effect would likely raise the objection that treating residential associations as state actors would infringe upon property rights. While this is a valid claim where a single developer has built a residential community on a previously deserted site, it becomes less persuasive if taken to mean that neighborhoods can simply decide to secede and take formerly public streets and parks with them. ${ }^{163}$ Such an objection in the latter context relies on a willful confusion between private and public property. As the Whitley Heights court objected, 'If the streets are still 'public,' it makes no sense to classify them as public when it comes to the expenditure of public funds, but classify them as private when it comes to public use. [The association] cannot have it both ways." 164 One theorist explains that "the association of the municipal corporation with home and family provides a stronger foundation for legal localism .... At the same time, it obscures the perception of local government as a state institution and thus erodes the longstanding legal rule that local

162. The statutory authority for remedying such actions would be provided by 42 U.S.C. $\$ 1983$, which establishes civil liability for any deprivation of right "under color of" state law. See, e.g., Lugar v. Edmondson Oil Co., 457 U.S. 922, 924 (1982). Note that this statute did not come into play in Laguna Publishing Co. v. Golden Rain Found., 182 Cal. Rptr. 813, 832 (Ct. App.), appeal dismissed for want of a substantial federal question, 459 U.S. 1192 (1982), as plaintiff neither pleaded nor proved a right to damages under this section.

163. Hence a frequently advanced justification for exclusive communities is not applicable here. A common formulation of the argument is that "the owner's right to exclude [is] 'one of the most essential sticks in the bundle of rights that are commonly characterized as property." Loretto $v$. Teleprompter Manhattan CATV Corp., 458 U.S. 419, 433 (1982) (quoting Kaiser Aetna v. United States, 444 U.S. 164, 176 (1979)). Apart from the troubling imagery of the fasces this metaphor evokes, this argument presumes that one has a legitimate claim to the property in question. For reasons given supra Section II.C., public property should not simply be doled out to exclusive communities on demand. Even if this transfer has occurred, the degree of state involvement may continue to be so great that the assertion of private rights may simply be a pretext for the assumption of state power. As McKenzie puts it, residential associations "represent the de facto privatization of local government services for the few." MCKENZIE, supra note 2, at 26.

164. Citizens Against Gated Enclaves v. Whitley Heights Civic Ass'n, 28 Cal. Rptr. 2d 451, 457 (Ct. App. 1994). 
government actions are attributable to the state." 165 The analysis advanced by this Note is committed to preserving this rule. The secession of a residential association is not a simple land transaction. If seceding neighborhoods merely assert their dominion over certain streets without compensation, the public at large is robbed of the resources it invested in the streets and parks now under private control. Even if local governments allow neighborhoods to secede only if they offer compensation, we still run the danger of reducing public space to isolated ghettoes too poor or unorganized to fend for themselves, exacerbating class and racial disparities, and balkanizing society.

The second major effect of treating residential associations as state actors would be an end to the role manipulation through which residential associations enjoy public powers without public responsibilities. The most likely and most desirable result is that residential associations would choose to forgo special advantages and rights allocated to them by state and local governments insofar as they do not want to be liable for the exercise of these advantages to the detriment of members of the public. These associations would remain free, however, to regulate their own members' behavior. For example, a would-be gated community like Whitley Heights would be enjoined from prohibiting access to its streets while it would remain free to contract among its members to ensure that their houses and property not be used for business purposes, or to ban large dogs, or even to insist that houses be painted a certain color. ${ }^{166}$ Residential associations could also hire security personnel for the neighborhoods, install better lighting, or contract for improved garbage collection or snow removal. It may be that residential associations would choose to forgo some of their government-granted privileges if the benefits did not outweigh the costs. The members might conclude that the extra expenditures they make to preserve their community are too diffuse, as the funds they spend have the secondary effect of benefiting nonmembers. Still, this solution best controls the negative externalities of associations' actions without eliminating their basic right to associate in the first place. ${ }^{167}$

Of course, exposing residential associations to the magnified liability associated with the status of state actor might have a detrimental effect on their attractiveness to potential members. Some Americans may well be attracted by the possibility for racial and economic segregation provided by some

165. Briffault, supra note 37, at 382. See generally Barak-Erez, supra note 97 (arguing that extent of privatization requires expansion of state action doctrine).

166. Note that, in this regard, these suggestions will not allay the concerns raised by Richard Louv, who asks, "Will human individuality win out over the dictatorship of the condo proletariat?" Louv, supra note 86 , at 123 .

167. This would also alleviate the problem of the secession of the successful. See supra Section II.C. So long as the outside world has some impact on the community, members have an incentive not to forget about concerns external to the life of the association. 
associations. ${ }^{168}$ Yet courts should not weigh in on the side of protecting these prejudices. Holding associations liable as state actors strikes a balance between private and public goods, a balance that is protective of freedom of association yet skeptical of the value of illiberal enclaves. ${ }^{169}$ Associations may have security and private guards, but not security and private guards who disproportionately harass minorities. They may preserve or enhance property values, so long as these values are not achieved by erecting insurmountable barriers to entry. Finally, they may establish a heightened degree of privacy and separateness, so long as it does not come at the price of total abdication of civic responsibility. Applying a different standard of liability to residential associations will discourage the development of such associations only to the extent such associations are illiberal enclaves rather than safe, supportive communities. Certainly, adherence to a standard of public rather than private liability may make existence more difficult for certain associations. Yet if some residential associations simply cannot exist without causing public harms, we might well question whether they should be formed in the first place.

\section{CONCLUSION}

This Note has attempted to present an appropriate framework to enable courts to evaluate the effects of residential associations on nonmembers. The explosive growth and popularity of residential associations can, if ignored, impose a variety of harms on nonmembers, who are affected by exclusion, discrimination, and a disintegrating tax base. Such are the results when residential associations wield quasi-governmental power without any of the concomitant obligations. By suggesting that the standard of judicial review of a residential association's behavior match the nature of the power the association enjoys, this Note hopes to limit the negative externalities that stem from the exercise of the association members' right to freedom of association. Finding that residential associations are state actors can effectively put an end to practices of discrimination and exclusion. This analytical framework will help weed out the negative aspects of residential associations while preserving those features that benefit members at no cost to the public. Of course, the ability to reside in certain communities will always be dependent on social class. The real question is whether such communities should be allowed to assume governmental powers without governmental responsibilities.

168. This possibility is demonstrated by the fact that "whites are willing to pay more for the occupancy of real property provided they reside in the vicinity of other whites." 2 U.S. COMM'N ON CIVIL RIGHTS, ISSUES IN HOUSING DISCRIMINATION 4 (1986), quoted in Ford, supra note 40, at 1849 n.15.

169. It might be objected that the very reason members join secessionist associations is to escape from governmental responsibilities. However, subjecting the behavior of associations to state action review is not an affirmation or expansion of their responsibilities toward government, but a recognition that they owe a minimum level of responsibility to the public at large. 
